\title{
Intentional Interpretation of the Poetic Text as a Key to the Author's Self-Concept
}

\author{
Volkov Sergey Alexandrovich ${ }^{1}$ \\ Associate Professor of Higher Institute of Languages of Tunis, \\ Carthage University \\ Tunisia, Republic of Tunisia.
}

(date of receiving: November, 2017; date of acceptance: February, 2018)

\begin{abstract}
Author's self-concept within our meaning is the self-presentation of rhymes in the content-related structure and reveals itself in the context of intentional interpretation of the poetic text, i.e. decoding the subject-matter and ideology rooted in it, complex of imageries and symbolic components. Hitting a target in seeking the key to the author's self-concept is undertaken through the case study work with The Spring Quran, a piece of poetry by the poet of the Silver Age of Russian literature $(1890-1922)$, "the son of Asia" Velimir Khlebnikov and is confined in interpreting implications used by the author in connection with the certain sources and motives, i.e. symbolic performance as of mythological and religious (both Christian-like and Muslim). Khlebnikov's "I" - selfconcept - in the poem The Spring Quran implicates the author's creed, aiming for the veracity through the tree of knowledge and admitting the religious values, faith in divine justice. Therefore the author's self-concept is the artistic oneness of truth-centered postulates and author's intentions to give utterance to them, identity of imageries and oneself. Interpreting the imageries and symbols of theologian, poplar, horn, sky, green, blue, etc. interlaced in the poem proves our case.
\end{abstract}

Keywords: Author's Self-Concept, Intentional Interpretation, Linguistic and Culturological Approach, Poetic Text, Symbols.

1. E-mail: sergei.volkov74@gmail.com 


\title{
Интенциональный анализ поэтического текста как «разгадка» авторского «я»
}

\author{
Волков Сергей Александрович ${ }^{1}$ \\ Доцент Высшего института языков Туниса Университета Карфагена, \\ Тунис, Тунисская Республика. \\ (дата получения: ноябрь 2017 г.; дата принятия: февраль 2018 г.)
}

\begin{abstract}
Аннотация
Авторское «я» нами понимается как самопредставление автора поэтического произведения в содержательной структуре, которое раскрывается в интенциональном анализе текста, те. расшифровке заложенных в нем тематикоидейной направленности, совокупности образов и символических элементов. Попытка «разгадки» авторского «я» предпринимается на примере стихотворения поэта эпохи Серебряного века Велимира Хлебникова («сына Азии», как он сам себя называл) «Весеннего Корана» и заключается в толковании смыслов, связанных с источниками и мотивами использования автором конкретных символических образов, в том числе мифологических и религиозных, как христианских, так и мусульманских. Хлебниковское «я» в «Весеннего Корана» заключает в себе мировоззренческую концепцию автора, а именно: стремление к истине через познание и принятие религиозных смыслов, веру в божественную справедливость. Отсюда авторское «я» - художественный опыт единства истинных постулатов и интенций автора выразить их, идентичность художественных образов и самого себя. Интерпретация перемежающихся образов и символов богослова, тополя, рога, невода, рыбы, столба, неба, зеленого, синего и др. доказывают нашу позицию.
\end{abstract}

Ключевые слова: Авторское «Я», Интенциональный Анализ, Лингвокультурологический Подход, Поэтический Текст, Символ.

1. E-mail: sergei.volkov74@gmail.com 


\section{Введение}

Поэтический текст представляется нам категорией, в которой репрезентируются в своей целостности личностный и лингвистический факторы речетворчества. Личностный фактор - это фактор субъекта автора как психологического, социального и культурного индивида со своим духовнохудожественным опытом. За лингвистический фактор здесь условно принимается авторский опыт оперирования языковыми средствами для воплощения в поэтической форме принципа эстетического и мировоззренческого самоопределения. Как видно, личностный и лингвистический факторы связаны между собой косвенно, именно поэтому в поэтическом творчестве текст можно считать «проводником» в соотношении «личность - язык». Это позволяет прийти к мысли о том, что поэтический текст, так же, как и текст вообще, - это категория лингвокультурологическая, но с особо выраженной авторской спецификой, требующей обозначения точек соприкосновения с общекультурными понятиями. Такая специфика поэтического текста - не что иное, как присутствие в нем авторского «я». Понимание сущности взаимообусловленности авторского «я» и лексических средств (не только как языковых, речевых и лингвокультурных единиц, но и как речетворческих установок для создания неповторимой образной картины «не-воображаемого» мира) достигается через интенциональный анализ содержательной структуры поэтического текста. В содержательную структуру нами включаются сюжетная линия и такие композиционные единицы текста (его художественной формы), как образы, символы, порождаемые темой слова, а также скрытые мотивы, побудившие автора к написанию произведения. Такие мотивы могут определяться мимолетным настроением или целевым поведением, при этом одно не исключает другого. В любом случае мотивы обусловлены историческими событиями, изменяющими культурную ситуацию и нравственное состояние общества, и биографическими фактами. 
В данной статье на примере интенционального анализа текста стихотворения «Весеннего Корана» мы ставим цель раскрыть авторское «я» его создателя Велимира Хлебникова, уроженца Астрахани - «восточной столицы» России, человека, философа, ученого, глубокого знатока цивилизации Востока, в частности персидской и арабской, мировых религий и мифологии, поэта эпохи Серебряного века, приверженца символической поэзии и одного из идеологов футуризма.

\section{Основная часть}

В поле зрения исследователей анализируемое нами стихотворение попадало как образец нового поэтического творчества о природе. И только Х. Баран сосредоточивается на семантике текста и отмечает разницу видения «природы у Хлебникова, в котором реальное и воображаемое, природное и мифическое, субъективное и объективное неразрывно переплелись» (Баран 1993. 93), и в русской поэзии Золотого века. Всесторонняя характеристика стихотворения в связи с его местом в литературном процессе начала XX века и в развитии восточной тематики в русской культуре дана С. Заху в магистерской диссертации «Восточные мотивы в русской поэзии Серебряного века (на примере произведений Велимира Хлебникова «Весеннего Корана» и «Хаджи-Тархан»)» (2017), выполненной и защищенной под руководством автора настоящей статьи.

В нашем, одновременно психолингвистическом и лингвокультурологическом подходе, мы опираемся на утверждение, что «интенциональность выражает предметную направленность переживаний сознания, его соотнесенность с предметами опыта. Эта соотнесенность сознания и предмета понимается как смыслообразующая, сознание есть не что иное, как смыслообразование» (Словарь философских терминов 2005. 204).

Приведем текст данного поэтического произведения. 
Весеннего Корана

Веселый богослов,

Мой тополь спозаранок

4 Ждал утренних послов.

Как солнца рыболов,

В надмирную синюю тоню

Закинувши мрежи,

Он ловко ловит рев волов

И тучу ловит соню,

10 И летней бури запах свежий.

О, тополь-рыбак,

Станом зеленый,

Зеленые неводы

Ты мечешь столба.
И вот весенний бог

(Осетр удивленный)

Лежит на каждой лодке

18 У мокрого листа.

Открыла просьба: «Небо дай»

20 Зеленые уста.

С сетями ловли бога

Великий Тополь

Ударом рога

Ударит о поле

25 Волною синей водки.

Весна 1919

(Хлебников 1986. 114).

Интенциональность хлебниковской поэтики (поэтики как художественного использования языковых средств) данного стихотворения выявляется в том, что, во-первых, каждое слово определяется «минимальной» темой, или подтемой, весь набор которых формирует сюжетную линию поэтического текста, во-вторых, каждая тема воплощает в себе конкретную интенцию и порождается главной авторской интенцией, которая задается в сознании целью создания произведения и проясняет его идею, в-третьих, применяется метод «максимального правдоподобия» определения авторских интенций на основе вероятности проявления совпадения культурно-смысловых параметров словсимволов в поэтическом тексте и источниках мировой культуры. В этой связи раскрытие интенциональности усматривается в установлении последовательности подтем и выведении общей темы и латентно-смысловом анализе атрибутов темы (слов-символов со скрытым содержанием). 
Чтобы говорить о том, какая интенция породила тему «Весеннего Корана», необходимо обратиться к мысли Хлебникова, которая мучила его до конца дней: «Моя цель - найти закон чистого времени, управляющий созвездием», записал он в своих «Мыслях и заметках» в 1920 г. (Хлебников 2006а. 90). Такой закон у Хлебникова сводился к уравнению, в котором соединялись «событие и противособытие во времени» и преломлялись «в его сухом языке» слова: «”Мне отмщение и Аз воздам”... Весь закон Моисея и весь Коран, пожалуй, укладываются в железную силу этого уравнения... Поступок и наказание, дело и возмездие» (Хлебников 2006б. 13).

В восточной тематике своего творчества Хлебников выражает одну из основных своих научных и мировоззренческих идей о соотношении времени и пространства. Эта идея заключалась в видении мира как единства, причем силу мира он в первую очередь относил к духовной силе Востока, в частности Персии, о которой писал в предисловии «Свояси» к своим «Творениям», что это «угол русской и македонской прямых» (Хлебников 1986. 36). Хлебниковская концепция времени родилась в его желании сломать «перо войны» (выражение Хлебникова из поэмы «Война в мышеловке»: Хлебников 1986. 462), «найти оправдание смертям», но не естественным, а насильственным, вызванным «жестоким законом отношения времени к месту» (выражения Хлебникова цит. по: Перцова 1994. 298-301), который действует в человеческом обществе в определенный исторический период.

Хлебников приблизился к открытию законов пространственно-временных отношений, предвидение которых может избавить мир от зла, и, по нашему мнению, в основе победы над временем и пространством заключена мысль о единении миров, цивилизаций через приход к Единому Богу, через поиск истины, веру в Судный день как очищение от грехов и приход к новому. Вот что он пишет в поэме «Азы из Узы» (1919-1922): «Я видел, что черные Веды, Коран и Евангелие, И ... Книги монголов ... сложили костер И сами легли на 
него - ... Чтобы ускорить приход Книги единой» (Хлебников 1986. 466). Сознание этой мысли и преломляется в художественной форме «Весеннего Корана».

Интенциональный анализ текста прежде всего требует выделения тем, или подтем, которые образуют сюжетную линию, затем описания интенций автора, способов их выражения и рассмотрения с точки зрения правдоподобности.

1. Ожидание послов спозаранок, очевидно, в то время, когда совершается первая молитва. Образы-символы: Коран, богослов, тополь, послы (строки 1 4).

2. Ловля. Образы-символы: рыболов, солнце, рев волов, туча соня, запах бури. Слова-символы: тоня, мрежи (невод, сети) (строки 5 - 10).

3. Улов. Образы-символы: тополь-рыбак, бог, осетр. Слова-символы: неводы, столб, лодка, лист (строки 11 - 18). Употребление слова бог в контексте ловли и улова, а у нас в написании с прописной буквы обусловливается не осознанием его Могущественным, Высшим Существом, а обозначением в языке различных воззрений о его сути или каких-либо божественных свойств.

4. Молитва. Взывание к небу, Богу о воздаянии. Образ просьбы (строки 1920).

5. Обретение мощи как ознаменование конца. Образы: Великий Тополь, сети, бог, удар рога, поле, волна, водка - вода (строки 21-25).

Первый стих Весеннего Корана относится ко всей композиции стихотворения. Интенция Хлебникова - не простое обращение к Корану. Он хочет показать его предназначенность, а именно то, что он несет в себе защиту, благую весть, наказание. Подтверждением такого понимания могут служить слова: «1. Та. Син. Это - аяты Корана и ясного Писания, 2. Верное руководство и благая весть для верующих, 3. Которые совершают намаз, выплачивают закят и убеждены в Последней жизни» (Сура 27 «ан-Намль» 
(«Муравьи»), аяты 1-3. 478 ${ }^{1}$ ). Коран назван весенним не только по времени написания этого произведения, ведь такое определение идеально отражает понимание художником слова Священной книги и придание ему символа начала природы, который воплощает в себе освобождение мира от хаоса.

Богослов: образ богослова, тополя, рыболова солнца, тополя-рыбака, с одной точки зрения, отождествляются, но, с другой стороны, в каждой теме приобретают дополнительные, переходные качества, как можно выразиться, по мере нарастания во времени и пространстве - от веселого богослова в надмирной тоне до Великого Тополя в поле. Один ли это образ в интенциональной структуре текста? Любовь Хлебникова к неоднозначности затрудняет ответ на этот вопрос. Однако мы можем позволить себе ассоциировать образ богослова с самим автором благодаря атрибуту весельй, тем более, что в Древней Греции богословами (теологами) называли поэтов, рассказывающих о богах. Не исключено поэтому намерение Хлебникова, вслед за Пушкиным, напомнить о том, что поэт - это глашатай слова Божьего. Это не противоречит и кораническому пониманию роли поэта: «224. А за поэтами следуют заблудшие. 225. Разве ты не видишь, что они блуждают по всем долинам (слагают стихи на любые темы) 226. и говорят то, чего не делают? 227. Это не относится к тем, которые уверовали, совершают праведные деяния, многократно поминают Аллаха и защищаются после того, как с ними поступают несправедливо, скоро узнают, куда они вернутся» (Сура 26 «аш-Шуара» («Поэты»), аяты 224-227. 477).

Тополь: Образ, имеющий целую мифологическую историю, отличающийся двойственностью «из-за того, что листья белого тополя - темные с верхней (солнечной) стороны и светлые с нижней (лунной)» (Словарь символов 1999. 371). Поэтому Хлебников воплотил в тополе свою интенцию видения единого

1. Тексты аятов в статье приводятся из источника, указанного в списке литературы: Священный Коран 1425 г.х. 
Бога, родства мусульманской и христианской религий. В другом своем произведении - «Слове о Эль» - Хлебников дает четкую характеристику тополю, связывая его этимологию с латинским наименованием populus - люди, народ:

Кто не лежит во время бега Его хребет стоит, как тополь,

Звериным телом, но стоит, А не лежит хребтом зверей.

Ему названье дали - люд. Прямостоячее двуногое,

Мы воду черпаем из ложки. Тебя назвали через люд.

Он одинок, он выскочка зверей, [Хлебников 1986. 121]

Мы приходим к выводу, что именно в значении люд фигурирует образ тополя в первой теме.

Тополь-рыбак: В атрибуте рыбак автор предлагает ассоциацию с Христом в связи с библейской притчей о Чудесном улове рыбы (Библия 2014. 5: 1-11. 1088-1089) и самим знаком рыбы как символом Иисуса Христа, наряду с солнцем.

Великий Тополь: Ассоциативный образ с ангелом Исрафилом: «В хадисе о Роге от Абу Хурайры говорится, что этот Рог огромного размера, и что его окружность величиной с небеса и земли. Ангел Исрафил будет дуть в него» (Коран онлайн). Интенция передать великое предназначение этого образа выражается даже в том, что слово Тополь в этом месте начертано с заглавной буквы.

Он (Тополь) - рыболов солнца : Этот образ у Хлебникова в разных «лицах» присутствует в его творениях (солнцелов, сыныл солнц̧а). В христианстве солнце - символ Христа: Христос - «Солнце правды» (Словарь символов 1999; Энциклопедия 2004. 465), а в исламе - «око Аллаха» (Энциклопедия 2004. 
461). Хлебников в теме ловли солнца хотел выразить интенцию о том, что солнце суть творчества, своими лучами проясняющее слово-истину, а «победа над солнцем» (которая и предполагается в ловле) - провозглашенный футуристами символ своей мифологизированной поэтики. Улов солнца у Хлебникова означает познание истины и переход от старого к новому через конец света. Достоверность нашей интерпретации образа рыболова солнца подтверждается научными источниками: «Солнце - атрибут персонифицированной истины, поскольку в его свете все становится ясным» (Холл 1996. 524) и «”Победа над солнцем” ... Это “переосмысленный футуристами Апокалипсис”, “метафора конца света”» (Губанова 1998. 69).

Посль: Интенция Хлебникова - поведать, кто может передать Божью волю людям на земле. Тема послов отсюда связана с ожиданием посланников Бога, явления ангелов, связанного с возвещением о конце света. Такое толкование объясняется апокалиптической сюжетной линией поэтического текста.

Атрибуты к образам Корана, богослова и послов весенний, весельий и утренние передают интенцию поэта о том, что уход старого знаменует рождение нового, то есть апокалиптические конец и начало - все те же переменные временных законов.

Авторская интенция - дать каждому понять, что ему не избежать Божъего слова - выражается в теме ловли. Местом ловли автор намеренно выбирает тоню - залив для ловли рыбы неводом, а также часть берега, прилегающую к нему, так как мы считаем, что он исходил из замысла написания стихотворения и символического отношения тони к концу жизни, в противовес воде - началу жизни.

Рев волов: Толкование рева волов можно связать с фольклорным представлением его как громом. Такого мнения придерживается исследователь Х. Баран при анализе стихотворения [Баран 1993. 88]. И это, в общем, логично, поскольку данный образ стоит в одном ряду с образами-явлениями природы 
(тучи и бури), формирующими подтему объектов ловли, так сказать, добычи. Мы расширим понимание этих слов, так как видим в них глубинный смысл, исходя из того, что Хлебников часто наполнял свои образы двойственным значением, предоставляя читателю возможность поразмыслить. Поэт «выбирает» образ не быка - символа солнечного начала и плодовитости, в исламской традиции опоры мира, а именно вола как лунного символа еще у древних египтян, в христианской религии ассоциирующегося, с одной стороны, с жертвой (что, очевидно, связано с лишением его способности к плодовитости), в которую принес себя Христос (Словарь символов 1999. 45 46). Вол «появляется в качестве жертвенного животного в очищении храма» и, наряду со львом, орлом и ангелом, является «апокалипсическим» существом (Холл 1996. 138). В исламе слывет плохим предзнаменованием, но в то же время это знак благоприятный, приносящий пользу (Dictionnaire des symboles musulmans 1995. 73). Кроме этого, вол как символ терпения соотносится с обязанностью мусульманина быть долготерпимым. Образ двойственен, хотя атрибут рев вносит дополнение о том, что здесь просматривается страдание, вызванное приписываемым волам долгим терпением, а в результате, с нашей точки зрения, делается упор на символ жертвенности, связь с концом света. К тому же автор подвергает ловле не самих волов, а их рев.

Туча соня: в Коране о тучах речь идет в аподиктическом стиле, когда объясняется, какая роль им отводится в великом природном цикле: «Он - Тот, Кто показывает вам молнию, чтобы вы боялись и надеялись, и создает тяжелые тучи» (Сура 13 «Ар-Рад» («Гром»), аят 12. 305). Туча как «знамение», средство «поучительного наказания» для неверующих, а атрибут соня (дополняющий нынешний характер состояния тучи) выполняет роль потенциального карательного меча. Тема ловли тучи объясняется нами как воплощение интенции показать «победу над пространством»: туча, гром, буря - предзнаменование сближения неба с землей. 
Атрибуты рев, соня, заnax - средства для выражения интенции о возвещении событий (дающих о себе знать волов с помощью рева, надвигающихся тучи и бури), а не об их факте.

Невод, мрежи, (рыболовные) сети: Образы-символы ловли. Интенция автора заключается в соотнесении этих слов с пониманием их в Священных Писаниях. «Еще подобно Царство Небесное неводу, закинутому в море и захватившему рыб всякого рода, который, когда наполнился, вытащили на берег и, сев, хорошее собрали в сосуды, а худое выбросили вон. Так будет при кончине века: изыдут Ангелы, и отделят злых из среды праведных, и ввергнут их в печь огненную; там будет плач и скрежет зубов» (Библия 2014. Мф. 13: 47-50. 1030). Также сеть олицетворяет силу, которую показал Христос своим ученикам в Чудесном улове рыбы (Библия 2014. 1088-1089). В исламе, начиная с персидской традиции, сеть считается мистическим средством постижения Бога. Невод в теме ловли в сочетании с атрибутом столб и действием глагола метать, совершаемым тополем-рыбаком, с одной стороны, подобен молнии, описанной в Коране: «Гром прославляет Его хвалой, а также ангелы от страха перед Ним. Он мечет молнии и поражает ими, кого пожелает. Они спорят об Аллахе, а ведь Он силен и суров в наказании» (Сура 13 «ар-Рад» («Гром»), аят 13. 305). С другой стороны, в этой теме интенциональность Хлебникова состоит в осознании невода, сплетенного из звезд, как символа небесного, улова pыбы - земного, а столба - моста между небом и землей - пространственного единства. Хлебников пишет в одной из своих микропоэм: «Годы, люди и народы Убегают навсегда, как текучая вода. В гибком зеркале природы Звезды - невод, рыбы - мы, Боги призраки у тьмы»(Хлебников 1931. 7). Мы практически всегда видим у него двойственный характер одного образа (например, рыба здесь ассоциируется с земным и далее - божественным), что отвечает его главной интенции доказательства единства, целостности кажущихся на первый взгляд несоединимых вещей. 
Употреблению трех слов фактически с одним значением, по нашему мнению, Хлебников придает особый смысл, располагая их появление как бы по временной вертикали, чем утверждается уходящее прошлое: мрежи устарелое слово, по звучанию мягкое и непредвещающее еще опасности, невод приближен к воде и служит для ловли с целью отбора хорошего и плохого улова (праведников и грешников), сети - средство возмездия. В этом видится опять-таки его интенция представить течение времени по особому закону.

Интенция обрисовать возмездие в тексте присутствует в единстве с мыслью показать пути спасения человека. Тема лодки, на наш взгляд, используется в качестве символа храма, путь к которому в христианстве означает покаяние и спасение. Мы можем предположить, что Хлебников стремился найти аналогию христианского символа лодки с мусульманским представлением о спасении и проводит ее со столбом, который сопутствуется или представляется неводом и устремляется ввысь, подобно минарету, предвещая спасение тем, кто уверовал. Между прочим, вариант этого слова столn в русскую старину имел значение сторожевой башни, на самом верху которой находилось помещение, служившее жилищем для затворников либо приспособленное под часовню. То есть столб связан с местом для молитв и в христианской традиции, которая восходила к языческим культам. Здесь слово столб может быть истолковано и как один из пяти столпов Ислама - намаз, ежедневная молитва, совершаемая пять раз, или хадж, в ходе которого паломники в день праздника жертвоприношения бросают по 7 камешков в «большой столб (джамрат аль-кубра), символизирующий шайтана» [Исламский энциклопедический словарь 2007. 759]. Хадж - это путь мусульман к спасению, ведущий в Мекку к Каабе: «96. Воистину, первым домом, который был воздвигнут для людей, является тот, который находится в Бекке (Мекке). Он был воздвигнут как благословение и руководство для миров. 97. В нем есть ясные знамения - место Ибрахима (Авраама). Кто 
войдет в него, окажется в безопасности. Люди обязаны перед Аллахом совершить хадж к Дому (Каабе), если они способны проделать этот путь. Если кто не уверует, то ведь Аллах не нуждается в мирах» (Сура 3 «Аль Имран» («Семейство Имрана»), аяты 96, 97. 73).

Осетр: Образ хлебниковский. Выбран им потому, что распространен осетр в дельте Волги, родных местах Хлебникова и, очевидно, поэт хорошо знаком с нравами этой рыбы с особенным взглядом наивного существа, с его невероятной способностью к плодовитости, поэтому уподобляет богу как началу и концу всего сущего, возможно благодаря. Кроме этого, своим внушительным внешним видом и необычной формой головы он под стать царствующей особе. Именно его поэт удостаивает права на спасение. Объяснение этому мы найдем в интерпретации интенционального смысла последующих слов-символов.

Лист можно представить как символ языка, который должен провозгласить правду, истину, но лишь тогда, когда наступит время. Здесь мы проводим параллель с историческими событиями, связанными с сопротивлением сирийцев в борьбе за власть четвертому Праведному халифу Али ибн Абу Талибу, двоюродному брату и зятю пророка Мохаммеда, и в которых листы Корана сыграли решающую роль: предвидя поражение, сирийцы по приказу своего правителя «нанизали на кончики копий листы Корана и призвали Али к Божьему суду» (Исламский энциклопедический словарь 2007. 50). Об этом явно знал Хлебников как знаток и исследователь Востока. Нет сомнения в том, что в тексте лист в каждой лодке значит лист Корана с «Ниспосланием от Господа миров»: «189. Они сочли его лжецом, и их постигли мучения в день тени. Воистину, это были мучения в Великий день. 190. Воистину, в этом знамение, но большинство их не стали верующими. 191. Воистину, твой Господь - Могущественный, Милосердный. 192. Воистину, это - Ниспослание от Господа миров. 193. Верный Дух (Джибрил) сошел с ним 194. на твое 
сердце, чтобы ты стал одним из тех, кто предостерегает. 195. Оно ниспослано на ясном арабском языке» (Сура 26 «аш-Шуара» («Поэты»), аяты 189-196. 474475) (в аяте 189: его значит Mycy). В теме листа скрыта интенция автора отразить мысль о сущности времени как средства обнаружения истины.

Просьба молит Бога послать бурю. Ее молитва была услышана. Интенция автора: посланник Бога - Аллаха (о чем свидетельствует атрибут образа просьбы зеленые уста) возвестит о Судном дне, наступление которого так описано в Коране: «В тот день подуют в Рог, и в тот день Мы соберем грешников синими (синеглазыми)» (Сура 20 «Та Ха» («Та Ха»), аят 102. 398). Tom день значит День Воскресения, или Судный день. В исламе этот день связан с воскрешением всех мертвых, отсюда и его название.

В поэтическом тексте образ-символ Великий Тополь обретает могущество, позволяющее вершить правосудие над несправедливостью (в той системе перемежающихся «миров» гражданской войны, в которой жил Хлебников). Атрибутами такой власти автор делает сети ловли бога, который, в нашей интерпретации, выступает символом начала и конца всего сущего, и рог божественная сила, сила души - символ солнечный и лунный. Интенция Хлебникова в использовании образов сетей и рога заключается в открытии жизненного принципа - постижения Бога, а значит и истины. Эта мысль гармонично сочетается со словом-образом волна, символизирующим хлебниковскую идею о событии и противособытии во времени. Тем самым еще раз подчеркивается интенция изобразить «победу» над временем и пространством в выражении ударит о поле волною (где поле - место, а волна время), соотносимом с представлением о конце света. Мы можем предположить, что Хлебников, употребляя в своем тексте стихотворения слово водка относил читателя к народному пониманию выражения водка богов, означающего дождь, то есть воду. Важно отметить, что в контексте Судного дня в Коране и у Хлебникова присутствует атрибут синий. В толковании слов 
Аллаха из аята 102 суры «Та Ха» «... и в тот день Мы соберём грешников синими (синеглазыми)» Саади пишет: «Богобоязненные праведники будут собраны перед милостивым Аллахом почтенной делегацией, а грешники изменятся в облике до неузнаваемости. От страха, переживаний и невыносимой жажды они станут синими...» (Ас-Саади 2012).

Сочетание синяя водка в поэтическом тексте выражает интенцию автора показать смертоносную сущность, которую несет в себе вода в день Страшного Суда, т.е. это гнев Божий: «Вожди Иудины стали подобны передвигающим межи: изолью на них гнев Мой, как воду» (Библия 2014. Ос. $5: 10.866)$.

Следует обратить внимание, что в тексте стихотворения неоднократно появляются цветовые атрибуты образов. Их понимание мы также связываем с заложенными в интенциях автора его законами и соотносим их с пространственно-временными свойствами.

Изумрудно-зеленый цвет является христианской эмблемой веры. Духовный символизм зеленого цвета «наиболее важен в исламском мире, где он был священным цветом Пророка и Божьего провидения» (Словарь символов 1999. 108). В языческом Египте зеленый цвет встречается на изображениях бога Осириса и символизировал его роль как бога смерти и новой жизни (Словарь символов 1999. 109).

Второй цветовой символ, который использует Хлебников в своем стихотворении, - это синий. Это цвет неба. В Египте он символизировал истину. Значение синего у Хлебникова соотносится с цветом цветка василька. Он пишет в статье «О пяти и более чувств $<\mathrm{ax}>»$ : «...Так есть величины, с изменением которых синий цвет василька..., непрерывно изменяясь, проходя через неведомые нам, людям, области разрыва, превратится в звук кукования кукушки или плач ребенка, станет им» (Хлебников 1940. 319). То есть для Хлебникова синий - символ трагического, связанного со смертью. 
Следовательно, приведенный нами интенциональный анализ поэтического текста позволяет утверждать, что интенциональность Хлебникова заключается в стремлении «послать» людям «опыт» того, в соответствии с его законами, что изменит реальный мир. Слово «опыт» здесь не случайное, если основываться на хлебниковском законе времени. В этом и состоит авторское «я» поэта.

\section{Заключение}

Поэтический язык Велимира Хлебникова глубоко философичен, что проявляется в наполнении содержания слова смыслами, впитавшими в себя опыт и мудрость человеческую с древних времен, европейскую и азийскую, и мудрость Божью. Прочтение каждого его произведения требует применения большого мыслительного труда и знаний, чтобы понять хотя бы частично его собственную мудрость, которая объединяет в себе заумь и научный язык, постижение силы слова и придание ему нестандартного звучания, постановку перед собой глобальной задачи и поиск пути ее решения через преодоление условностей бытия, поиск истины в ее идеале, накопленные знания и умение их выразить с отдачей, умение целесообразно применить свои законы. В этом и состоит кредо Хлебникова, его «я», которое реализуется в его творениях. Разгадать это авторское «я» невозможно путем прохождения школы знаний Хлебникова. Необходимо проникнуться его духом, поэтому наше внимание в статье и было обращено на интенциональный анализ его текстов.

\section{Литература}

1- Ас-Саади, Абд ар-Рахман бин Насир (2012). Толкование Священного Корана «Облегчение от Великодушного и Милостивого» / Пер. с араб. Э. Кулиев. Москва: Изд-во «Умма». [Электронная версия].

2- Баран Х. (1993). Поэтика русской литературы ХХ века: Сборник. Москва: Издательская группа «Прогресс» - «Универс». 
3- Библия: Книги Священного Писания Ветхого и Нового Завета (2014). Москва: Изд-во «Российское Библейское общество».

4- Губанова Г. (1998). Групповой портрет на фоне Апокалипсиса (к проблеме толкования «Победы над Солнцем» // Литературное обозрение. № 4. С. 69-77.

5- Исламский энияиклопедический словарь (2007) / Али-заде А. Москва: Изд-во «Ансар».

6- Коран онлайн. URL: http://quran-online.ru/20:102. (Дата обращения: 09.02.2018).

7- Перцова Н.Н. (1994). Об «уравнениях рока» Велимира Хлебникова // Понятия судьбы в контексте разных культур. Москва: Изд-во «Наука». С. 298-301.

8- Священный Коран: Смысловой перевод на русский язык (1425 г.х.) / Пер. с араб. Кулиева Эльмира. Первое изд. Медина, Саудовская Аравия: Комплекс имени Короля Фахда по изданию священного Корана.

9- Словарь символов (1999) / Тресиддер Дж. / Пер. с англ. С. Палько. Москва: Изд-во «Фаир-Пресс».

10- Словарь философских терминов (2005) / Научная редакция профессора В.Г. Кузнецова. Москва: Изд-во «ИНФРА-М».

11- Хлебников В. (1931). Собрание произведений Велимира Хлебникова / Под общ. ред. Ю.Тынянова и Н.Степанова. Том III. Изд-во писателей в Ленинграде.

12- Хлебников В. (1940). Неизданные произведения / Под ред. Н. Харджиева и Т. Грица. Москва: Гос. изд-во худ. лит.

13- Хлебников Велимир (1986). Творения. Москва: Изд-во «Советский писатель».

14- Хлебников В. (2006а). Мысли и заметки. Собрание сочинений: В 6 тт. Т. 6. Книга вторая. Москва: Изд-во «ИМЛИ РАН». С. 73-104.

15- Хлебников В. (2006б). Слово о числе и наоборот. Собрание сочинений: В 6 тт. Т. 6. Книга 2-ая. Москва: Изд-во «ИМЛИ РАН». С. 9-29.

16- Холл Дж. (1996). Словарь сюжетов и символов в искусстве. Москва: Изд-во «КРОН-ПРЕСС».

17- Энцииклопедия. Символь, знаки, эмблемы (2004) / Авт.-сост. В. Андреева и др. Москва: ООО «Изд-во Астрель»: ООО «Изд-во АСТ».

18- Dictionnaire des symboles musulmans : Rites, mystique et civilisation (1995) / Malek Chebel. Paris: Editions Albin Michel S.A. 


\section{Bibliography}

1- As-Saadi, Abd ar-Rahman bin Nasir (2012). Tolkovanie Svjashhennogo Korana «Oblegchenie ot Velikodushnogo i Milostivogo» / Per. s arab. Je. Kuliev. Moskva: Izd-vo «Umma». [Jelektronnaja versija].

2- Baran H. (1993). Pojetika russkoj literatury HH veka: Sbornik. Moskva: Izdatel'skaja gruppa «Progress» - «Univers».

3- Biblija: Knigi Svjashhennogo Pisanija Vethogo i Novogo Zaveta (2014). Moskva: Izd-vo «Rossijskoe Biblejskoe obshhestvo».

4- Gubanova G. (1998). Gruppovoj portret na fone Apokalipsisa (k probleme tolkovanija «Pobedy nad Solncem» // Literaturnoe obozrenie. № 4. S. 69-77.

5- Islamskij jenciklopedicheskij slovar' (2007) / Ali-zade A. Moskva: Izd-vo «Ansar».

6- Koran onlajn. URL: http://quran-online.ru/20:102. (Data obrashhenija: 09.02.2018).

7- Percova N.N. (1994). Ob «uravnenijah roka» Velimira Hlebnikova // Ponjatija sud'by v kontekste raznyh kul'tur. Moskva: Izd-vo «Nauka». S. 298-301.

8- Svjashhennyj Koran: Smyslovoj perevod na russkij jazyk (1425 g.h.) / Per. s arab. Kulieva Jel'mira. Pervoe izd. Medina, Saudovskaja Aravija: Kompleks imeni Korolja Fahda po izdaniju svjashhennogo Korana.

9- Slovar' simvolov (1999) / Tresidder Dzh. / Per. s angl. S. Pal'ko. Moskva: Izd-vo «Fair-Press».

10- Slovar' filosofskih terminov (2005) / Nauchnaja redakcija professora V.G. Kuznecova. Moskva: Izd-vo «INFRA-M».

11- Hlebnikov V. (1931). Sobranie proizvedenij Velimira Hlebnikova / Pod obshh. red. Ju.Tynjanova i N.Stepanova. Tom III. Izd-vo pisatelej v Leningrade.

12- Hlebnikov V. (1940). Neizdannye proizvedenija / Pod red. N. Hardzhieva i T. Grica. Moskva: Gos. izd-vo hud. lit.

13- Hlebnikov Velimir (1986). Tvorenija. Moskva: Izd-vo «Sovetskij pisatel'».

14- Hlebnikov V. (2006a). Mysli i zametki. Sobranie sochinenij: V 6 tt. T. 6. Kniga vtoraja. Moskva: Izd-vo «IMLI RAN». C. 73-104.

15- Hlebnikov V. (2006b). Slovo o chisle i naoborot. Sobranie sochinenij: V 6 tt. T. 6. Kniga 2-aja. Moskva: Izd-vo «IMLI RAN». C. 9-29.

16- Holl Dzh. (1996). Slovar' sjuzhetov i simvolov v iskusstve. Moskva: Izd-vo «KRONPRESS». 
17- Jenciklopedija. Simvoly, znaki, jemblemy (2004) / Avt.-sost. V. Andreeva i dr. Moskva: OOO «Izd-vo Astrel'»: OOO «Izd-vo AST».

18- Dictionnaire des symboles musulmans : Rites, mystique et civilisation (1995) / Malek Chebel. Paris: Editions Albin Michel S.A.

HOW TO CITE THIS ARTICLE
Volkov Sergey Alexandrovich (2018). Intentional
Interpretation of the Poetic Text as a Key to the Author's Self-
Concept, Issledovatel'skiy Zhurnal Russkogo Yazyka i
Literatury, 11(1): pp: 139-158.
DOI: $10.29252 /$ iarll.11.139


آناليز مفهومى متن منظوم به عنوان (كشف)" (من)" نويسنده

\author{
سر كئى الكسئى يويج وولكف \\ دانشيار انستيتوى عالى زبانهاى دانشگاه كارفاگن، \\ تونس، جمهورى تونس،

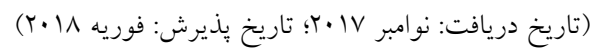

از نظر مؤلف مقاله، (من) نويسنده همان معرفى نويسنده در ساختار معنايى اثر منظوم است

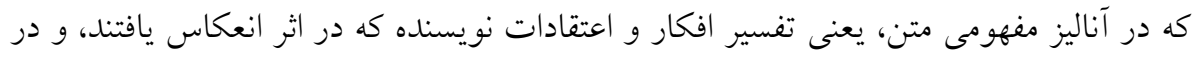

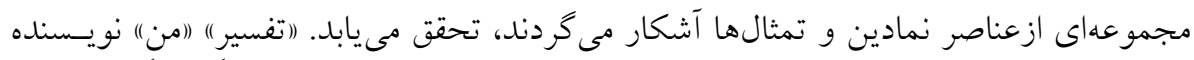

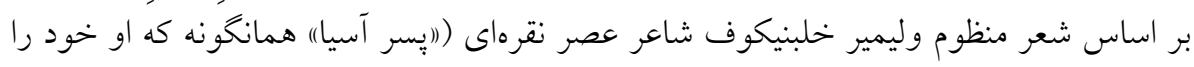

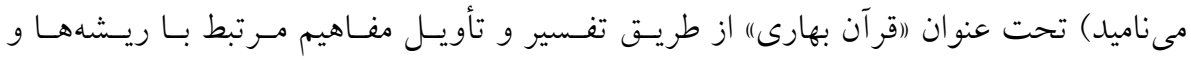

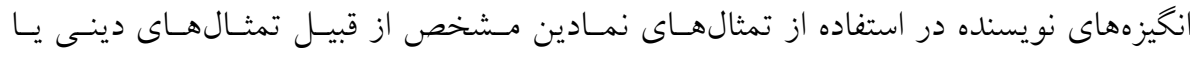

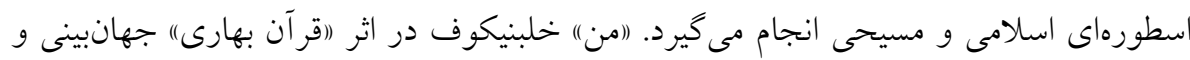

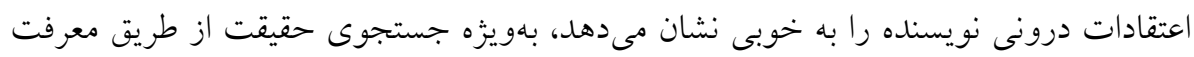

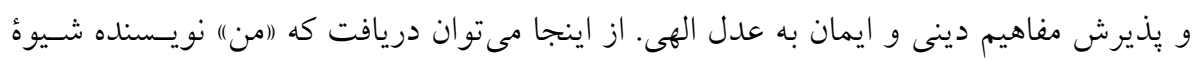

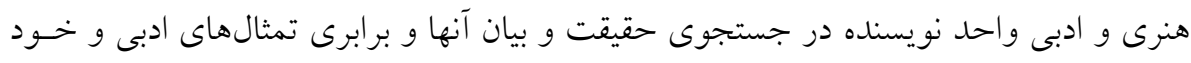

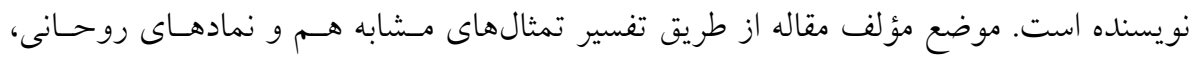

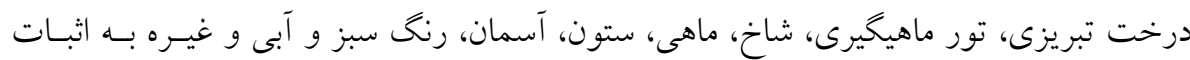
مىرسد. وازگًان كليدى: (من) نويسنده، آناليز مفهومى، رويكرد فرهنگى -زبانى، متن منظوم، نماد. 